\title{
Elevated temperature produces cystine depletion in cystinotic fibroblasts
}

\author{
Rosemary M. Lemons, Ronald L. Pisoni, Halvor N. Christensen \\ and Jess G. Thoene \\ Departments of Pediatrics and Biological Chemistry, The University of Michigan, Ann Arbor, MI 48109 (U.S.A.)
}

(Received 23 June 1986)

Key words: Cystinosis; Cystine transport; Temperature sensitivity; Heat shock

Increasing the incubation temperature of cystinotic fibroblasts to 40 or $43^{\circ} \mathrm{C}$ produces a $70-80 \%$ decrease in lysosomal cystine content within $24-48 \mathrm{~h}$. This effect is probably mediated by an altered substrate affinity for another lysosomal transport protein.

\section{Introduction}

The human disease, cystinosis, results from defective lysosomal cystine transport [1-3]. The consequences of this recessive mutation are lysosomal cystine storage and a number of clinical symptoms, chief among which is renal failure during childhood [4]. Transport of amino acids from lysosomes appears to be carrier-mediated, based on the findings of saturability and carrier specificity. At least three separate lysosomal amino acid transport systems have now been discovered: the previously mentioned system for cystine; a system which recognizes certain cationic amino acids (particularly lysine) [5]; and a system which mediates proline and, to a lesser extent, small neutral amino acids [6].

This paper describes an alteration in the transport properties of the cystinotic lysosomal membrane for cystine at elevated temperatures. The phenomenon appears not to be due to either the induction of a temperature-sensitive gene product or activation of the heat-shock response. It produces rapid depletion of cystine from cystinotic

Correspondence address: Dr. J.G. Thoene, Kresge II, R6028 The University of Michigan, Ann Arbor, MI 48109-0566, U.S.A. lysosomes and may be due to altered carrier affinity for a transport system which can recognize cystine only at higher temperatures.

\section{Materials and Methods}

Diploid epithelial fibroblast cultures were derived from skin biopsies of patients with nephropathic cystinosis and maintained in modified Ham's F12 medium [5], supplemented with 10\% (v/v) fetal bovine serum and incubated at 37,40 or $43^{\circ} \mathrm{C}$ in a humidified incubator flushed with an air $/ \mathrm{CO}_{2}(19: 1)$ mixture. Control fibroblasts were purchased from the Human Genetic Mutant Cell Repository. Cystine-free medium is the same medium with cystine deleted. Cells were harvested by trypsin treatment and immediately broken by ultrasonic disruption in the presence of $5 \mathrm{mM}$ $N$-ethylmaleimide in $100 \mu \mathrm{M}$ phosphate buffer $(\mathrm{pH}$ 7.4). Cell proteins were precipitated by the addition of $1 / 4$ vol. $12 \%$ sulfosalicylic acid and removed by centrifugation. The supernatant was analyzed for total free cystine via a cystine-binding protein assay [7]. Cell number was determined with a Coulter counter (Coulter Instruments, Inc., Hialeah, FL), Model ZF, and cell protein by the method of Lowry et al. [8]. Radioactivity was determined using a Beckman LS 100 liquid scintil- 
lation counter (Beckman Instruments, Inc., Fullerton, CA). Counting efficiency for $\left[{ }^{35} \mathrm{~S}\right]$ cystine was 94\%. Polyacrylamide gel electrophoresis was performed by the method of Laemmli [9] using a $4 \%$ stacking gel and a $10 \%$ analytical gel in the presence of $0.1 \%$ sodium dodecyl sulfate. Autoradiography was accomplished by exposure of the dried gel to X-ray film at $-70^{\circ} \mathrm{C}$.

Granular fractions were prepared from the various fibroblast cell lines as described previously [5]. Lysosomes were loaded with $\mathrm{L}_{-}\left[{ }^{35} \mathrm{~S}\right]$ cystine by incubating granular fractions with $0.3 \mathrm{mM}$ $\left[{ }^{35} \mathrm{~S}\right]$ cystine dimethyl ester in buffer A (morpholine/Tris/sucrose, $\mathrm{pH}$ 7) [5] for $60 \mathrm{~min}$ at $37^{\circ} \mathrm{C}$. Excess $\left[{ }^{35}\right.$ S $]$ cystine dimethyl ester was then removed by centrifuging the granular fractions twice in $1.5 \mathrm{ml}$ of buffer A containing $2 \mathrm{mM}$ $\mathrm{N}$-ethylmaleimide in an Eppendorf microfuge at $15600 \times \mathrm{g}$ for $10 \mathrm{~min}$ at $4^{\circ} \mathrm{C}$, discarding the supernatant after each centrifugation. The final granular pellet, containing the L- $\left[{ }^{35}\right.$ S $]$ cystineloaded lysosomes, was resuspended in $0.9 \mathrm{ml}$ buffer A containing $2 \mathrm{mM} N$-ethylmaleimide and exodus was initiated by incubation at $37^{\circ} \mathrm{C}$. Triplicate 70 $\mu 1$ aliquots were removed at the various time points, added to microfuge tubes containing 0.45 ml ice-cold buffer A with $2 \mathrm{mM} N$-ethylmaleimide and centrifuged for $10 \mathrm{~min}$ at $4^{\circ} \mathrm{C}$ in the Eppendorf microfuge. Supernatants were discarded and pellets were resuspended in $80 \mu 110 \mathrm{mM}$ sodium phosphate buffer (pH 7.0) containing $5 \mathrm{mM}$ $\mathrm{N}$-ethylmaleimide and processed for assay of total hexosaminidase activity and $\left[{ }^{35} \mathrm{~S}\right]$ cystine as previously described [5].

Exodus of $\left[{ }^{3} \mathrm{H}\right]$ cystathionine was measured in the manner described for $\left[{ }^{3} \mathrm{~S}\right]$ cystine except that $\left[{ }^{3} \mathrm{H}\right]$ cystationine $(0.033 \mathrm{mM})$ was loaded into fibroblast lysosomes for $75 \mathrm{~min}$ at $37^{\circ} \mathrm{C}$ and $\mathrm{N}$-ethylmaleimide was omitted from all the buffers. The dimethyl esters of cystine and cystathionine were prepared as described by Steinherz et al. [10].

\section{Results}

When cystinotic fibroblasts are shifted from $37^{\circ} \mathrm{C}$ to elevated temperatures, the effect on the intracellular cystine content is as shown in Fig. 1. After a lag period of approximately $6 \mathrm{~h}$, there is a progressive decline in the intracellular cystine con-

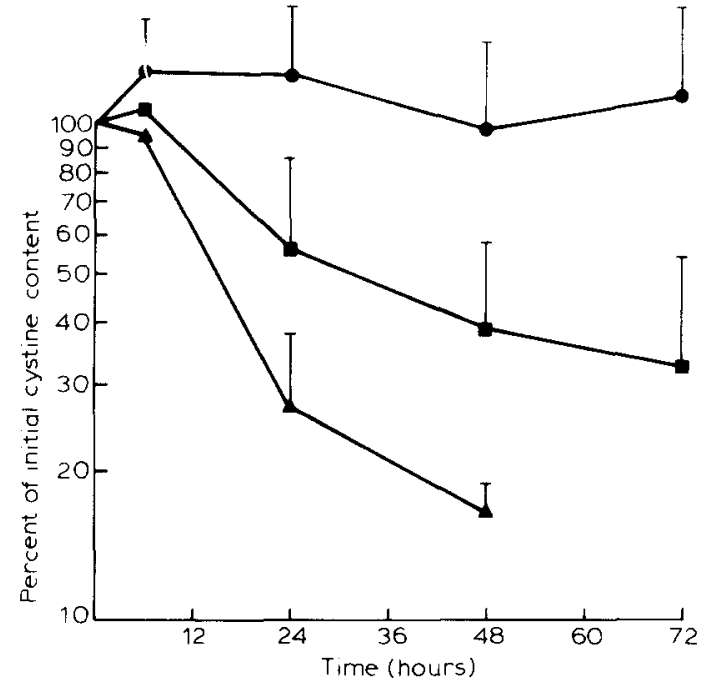

Fig. 1. The effect of elevated temperature on the cystine content of cystinotic fibroblasts. Plates of confluent cystinotic fibroblasts were maintained in complete (cystine-containing) media and either kept at $37^{\circ} \mathrm{C}(\bullet)$ or shifted to $40^{\circ} \mathrm{C}(\boldsymbol{\square})$ or $43^{\circ} \mathrm{C}(\Delta)$. The cells were harvested by trypsin treatment at the times indicated and the intracellular non-protein cystine content was measured via the cystine binding assay. Data are expressed as a percent of the initial value to facilitate comparison between various cystinotic cell lines whose initial cystine content varied. The control line is drawn from paired duplicate plates kept at $37^{\circ} \mathrm{C}$. The $40^{\circ} \mathrm{C}$ experiments were performed 12-15 times using duplicate plates. The initial cystine content in this series was $2.86 \pm 1.33 \mathrm{nmol}$ cystine $/ 10^{6}$ cells. The initial cystine content for the cells shifted to $43^{\circ} \mathrm{C}$ was $1.69 \pm 1.05$ nmol cystine $/ 10^{6}$ cells. This experiment was performed $4-6$ times using duplicate plates. Statistical analysis by Student's paired ' $t$ ' test demonstrated that the cystine content of the cells incubated at $40^{\circ} \mathrm{C}$ for 24,48 and $72 \mathrm{~h}$ differed from the matched controls with $P<0.05$. The cystine content of cells shifted to $43^{\circ} \mathrm{C}$ differed from paired controls by $P<0.05$ for the $24 \mathrm{~h}$ point and $P<0.1$ for the $48 \mathrm{~h}$ point. No significant difference in cystine content was found for the $6 \mathrm{~h}$ point at either temperature. Bars are means \pm 1.0 S.D.

tent compared to that of cells maintained at $37^{\circ} \mathrm{C}$ such that by $72 \mathrm{~h}$ at $40^{\circ} \mathrm{C}$, the residual cystine is only about $30 \%$ of that present originally. When cystinotic fibroblasts are shifted to $43^{\circ} \mathrm{C}$, the loss in cystine is more rapid; after $24 \mathrm{~h}$, the cystine concentration has fallen by $70 \%$ of the initial value, and less than $20 \%$ of the initial cystine content remains after $48 \mathrm{~h}$ of incubation.

Cell viability during and after exposure to elevated temperatures was determined by both trypan blue exclusion and incorporation of radio- 
active amino acids into acid-precipitable material. Routine tests of trypan blue exclusion during harvest after exposure to 40 or $43^{\circ} \mathrm{C}$ for periods of 24 to 48 h showed that over $90 \%$ of cells did not stain. The incorporation of radioactivity into normal and cystinotic cell proteins after $8 \mathrm{~h}$ exposure to $43^{\circ} \mathrm{C}$ showed $93.2 \%$ and $96 \%$ of the incorporation into protein found for normal and cystinotic cells kept at $37^{\circ} \mathrm{C}$.

To determine whether the exocytosis rate was increased at elevated temperatures, cystinotic fibroblasts were preloaded with the membrane-impermeant markers $\left[{ }^{3} \mathrm{H}\right]$ sucrose or ${ }^{125} \mathrm{I}$-polyvinylpyrrolidone. The clearance of these compounds from the lysosomal system was not enhanced at either 40 or $43^{\circ} \mathrm{C}$; actually, slightly more radioac- tivity remained in the cells incubated at the increased temperature than in cells maintained at $37^{\circ} \mathrm{C}$.

Heat-shock phenomena are evoked at elevated temperatures in cells of all phyla [11]. This process results in the termination of synthesis of most cell proteins and the initiation of synthesis of the 'heat-shock' proteins, along with an increase in overall proteolysis. To determine whether these phenomena were involved in the cystine depletion observed, cells were labeled with $\left[{ }^{35}\right.$ S]methionine at either 37,40 or $43^{\circ} \mathrm{C}$. On SDS-polyacrylamide gel electrophoresis analysis, no proteins were labeled at $40^{\circ} \mathrm{C}$ that were not also labeled at $37^{\circ} \mathrm{C}$ in either normal or cystinotic fibroblasts. However, after exposure to $43^{\circ} \mathrm{C}$, a new protein

\section{6}

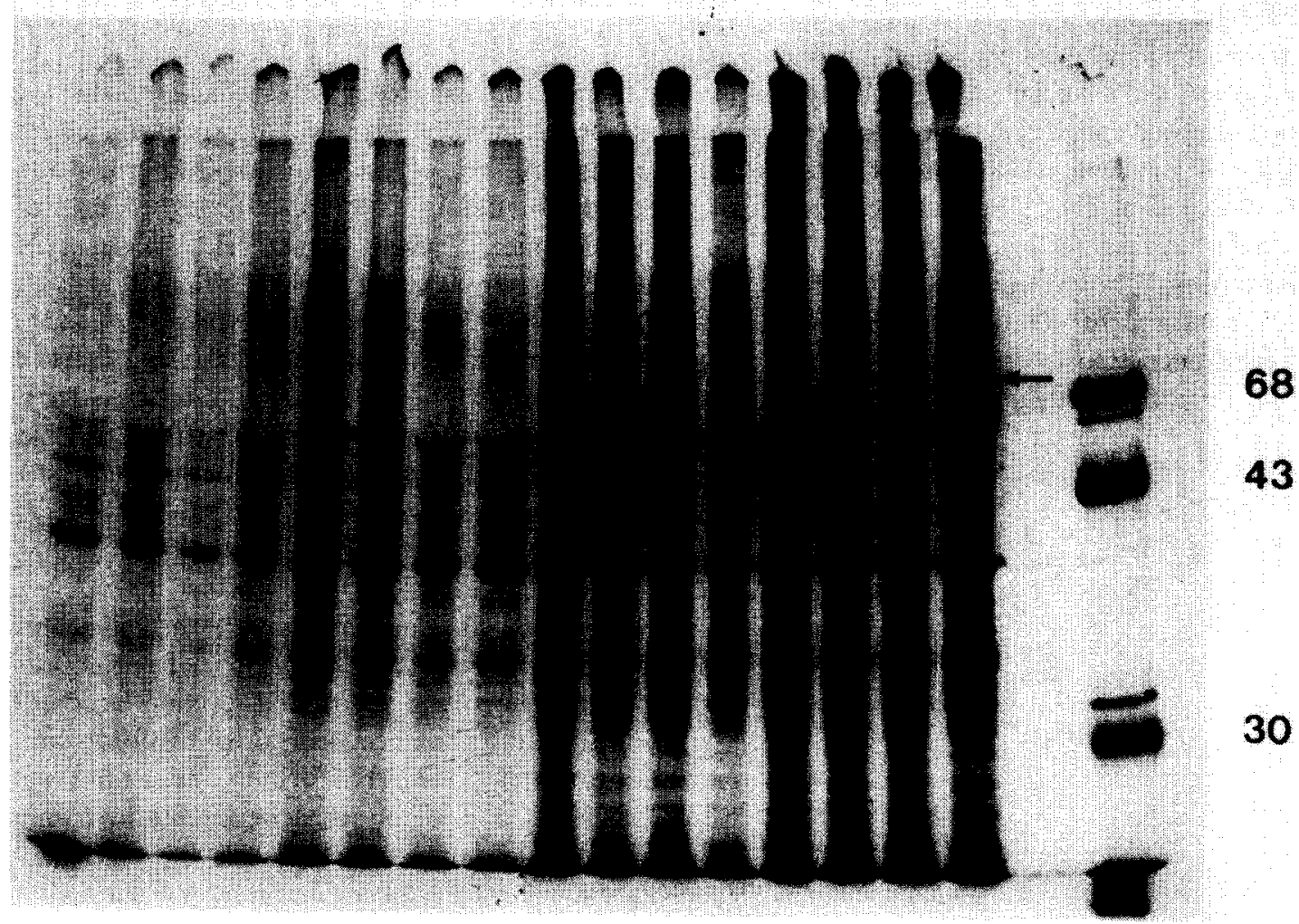

Fig. 2. Autoradiogram of cell proteins of normal and cystinotic fibroblasts after exposure to $\left[{ }^{35} \mathrm{~S}\right] \mathrm{methionine}$ at 37 or $43^{\circ} \mathrm{C}$ for $8 \mathrm{~h}$. In each group of four lanes, the first is a normal cell incubated at $37^{\circ} \mathrm{C}$ and the second is a normal cell at $43^{\circ} \mathrm{C}$, the third is a cystinotic cell at $37^{\circ} \mathrm{C}$ and the fourth is a cystinotic cell at $43^{\circ} \mathrm{C}$. Cells were harvested at $0.5,1,4$ and $8 \mathrm{~h}$ of incubation. Molecular weight markers are at the right of the figure. Note in this figure the presence of a band in lanes $10,12,14$ and 16 which is not present in the corresponding position of lanes $9,11,13$ and 15 . This presumably represents hsp 70 , a well characterized heat shock protein of $M_{\mathrm{r}}$ 70000 (arrow). 
was apparent at $M_{\mathrm{r}} 70000$ (Fig. 2). This corresponds to hsp 70 , the most commonly observed heat shock protein [11]. It is detectable in both normal and cystinotic fibroblasts after $4 \mathrm{~h}$ incubation at $43^{\circ} \mathrm{C}$, but was not observed after $40^{\circ} \mathrm{C}$ for periods of up to $24 \mathrm{~h}$.

Temperature-sensitive genes have been widely described in microorganisms and mutant fibroblasts [12]. To determine whether expression of a temperature-sensitive mutation was responsible for the observed cystine depletion effect, the depletion experiments were repeated in the presence of cycloheximide. Addition of $100 \mu \mathrm{M}$ cycloheximide to the culture medium did not produce inhibition of cystine depletion at $43^{\circ} \mathrm{C}$. After $24 \mathrm{~h}$ of incubation, cells exposed to $43^{\circ} \mathrm{C}$ without cycloheximide had lost $0.16 \mathrm{nmol}$ cystine $/ 10^{6}$ cells; those exposed to cycloheximide had lost $0.42 \mathrm{nmol} / 10^{6}$ cells. The initial cystine content of these cells was $0.71 \mathrm{nmol} / 10^{6}$ cells.

Cystine transport from isolated cystinotic granules was measured at 37,40 and $43^{\circ} \mathrm{C}$. The lysosomal fraction isolated from cystinotic fibroblasts grown at either 37 or $40^{\circ} \mathrm{C}$ whose rate of cystine exodus was measured at $37^{\circ} \mathrm{C}$ showed the typical delayed cystine egress characteristic of the cystinotic mutation. When efflux from cystinotic granules was measured at 40 or $43^{\circ} \mathrm{C}$, however, the efflux approached that of the normal cells at $37^{\circ} \mathrm{C}$ (Fig. 3). Lysosomal integrity, as determined

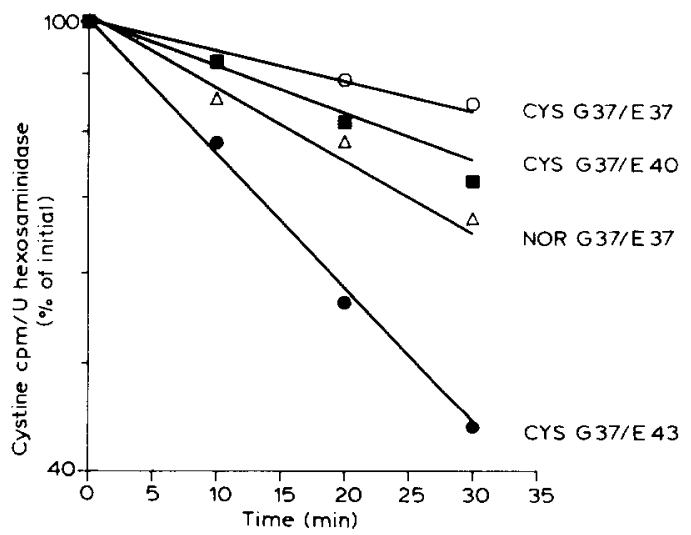

Fig. 3. Cystine exodus from cystinotic (CYS) and normal (NOR) lysosomes at 37,40 or $43^{\circ} \mathrm{C}$. The granular fraction was loaded with cystine to a level of $20 \mathrm{pmol} / \mathrm{U}$ hexosaminidase and prepared as described under Materials and Methods. Cells were loaded and grown $(\mathrm{G})$ at $37^{\circ} \mathrm{C}$ and the exodus (E) was measured at either 37,40 or $43^{\circ} \mathrm{C}$ as indicated in the figure.
TABLE I

EFFECTS OF $43^{\circ} \mathrm{C}$ ON LOSS OF $\mathrm{L}-\left[{ }^{3} \mathrm{H}\right] \mathrm{CYSTATHIONINE}$ FROM ISOLATED CYSTINOTIC LYSOSOMES

The granular fraction from cystinotic fibroblasts was incubated for $75 \mathrm{~min}$ at $37^{\circ} \mathrm{C}$ with $\mathrm{L}-\left[{ }^{3} \mathrm{H}\right]$ cystathionine dimethyl ester, collected by centrifugation. washed and resuspended in exodus buffer. Aliquots were removed at 0 and $30 \mathrm{~min}$ and centrifuged, then resuspended and assayed for ${ }^{3} \mathrm{H}$ and hexosaminidase activity. The initial loading of the fractions was 0.6 $\mathrm{pmol} / \mathrm{U}$ hexosaminidase. This is comparable to that obtained with other amino acids (e.g., lysine [5]). Analysis of the granular fraction by high voltage electrophoresis after $60 \mathrm{~min}$ of incubation showed no residual dimethyl ester. Figures in parentheses are percentages of zero-time values

\begin{tabular}{lll}
\hline $\begin{array}{l}\text { Time } \\
(\min )\end{array}$ & \multicolumn{2}{l}{$\begin{array}{l}\mathrm{L}-\left[{ }^{3} \mathrm{H}\right] \text { Cystathionine } \\
(\mathrm{cpm} / \mathrm{U} \text { hexosaminidase })\end{array}$} \\
\cline { 2 - 3 } & $37^{\circ} \mathrm{C}$ & $43^{\circ} \mathrm{C}$ \\
\hline 0 & $307 \pm 21$ & $307 \pm 21$ \\
30 & $266 \pm 18$ & $280 \pm 19$ \\
& $(86.6 \%)$ & $(91 \%)$ \\
\hline
\end{tabular}

by latency of $\beta$-hexosaminidase activity in the recovered lysomal pellets, was taken into account in measuring the egress rate (see Materials and Methods for details). Notably, the egress rate of cystathionine, a close structural analogue of cystine, was not greater at $43^{\circ} \mathrm{C}$ than it was at $37^{\circ} \mathrm{C}$ (Table I). No egress of cystathionine from the granular fraction of normal cells was observed (data not shown), hence failure to see egress from the cystinotic fraction can not be attributable to the presence of cystine in the cystinotic granules.

\section{Discussion}

The cystinosis mutation provides a convenient opportunity for the study of lysosomal proteolysis via measurement of lysosomal cystine accumulation from lysosomal proteolysis of disulfide-containing proteins [13]. To further understand the mechanisms of proteolysis, experiments involving exposure of cystinotic fibroblasts to elevated temperature were undertaken. The results described in this paper show that cystine depletion of cystinotic cells occurs rapidly after an initial lag period when these cells are exposed to $40^{\circ} \mathrm{C}$. This cystine depletion is not inhibitable by cycloheximide, and also occurs at a temperature $\left(40^{\circ} \mathrm{C}\right)$ at which heat-shock proteins are not induced in these 
fibroblasts. Furthermore, exocytosis is not increased at either 40 or $43^{\circ} \mathrm{C}$ and an enhanced rate of loss of the structural congener of cystine, cystathionine, is not produced in isolated cystinotic lysosomes at the increased temperatures.

The half-time for egress of cystine from isolated cystinotic lysosomes is increased at 40 or $43^{\circ} \mathrm{C}$ to a rate greater than or equal to the efflux rate for cystine from normal lysosomes (Fig. 3). This increased rate of egress was not observed when the lysosomes were isolated from cells grown at 40 or $43^{\circ} \mathrm{C}$, and exodus was measured at $37^{\circ} \mathrm{C}$, but was observed when the granular fraction was isolated from cells grown at $37^{\circ} \mathrm{C}$ and the exodus was measured at 40 or $43^{\circ} \mathrm{C}$. Hence a modification in the lysosomal membrane due to an alteration in membrane synthesis is not responsible for this effect. We interpret these results as being consistent with the recognition of cystine by another pre-existing transport protein in the lysosomal membrane only at the elevated temperature. The effect of temperature in producing cystine depletion is not due to alteration of the existing, but defective, cystine transport system in cystinotic lysosomes, since this effect has been observed in five cystinotic cell lines from unrelated families, including nephropathic, benign and intermediate forms of cystinosis. All these phenotypes demonstrate the abnormal lysosomal accumulation of cystine; however, only the nephropathic form produces renal disease by age 10 years. The intermediate form demonstrates a slower rate of loss of renal function, and the benign form has no renal involvement. The cause of these variants in biochemical terms is as yet unknown [4]. The same point mutation occurring in all five lines, each of which has its defective cystine transporting capability corrected by exposure to increased temperature, is considered highly unlikely. The correction is in some ways analogous to the previously described recognition of the cystine-cysteamine mixed disulfide by the lysine transport system after cystinotic cells are exposed to cysteamine [5]. In that case, chemical modification of cystine to the mixed disulfide of cystine and cysteamine permits lysosomal cystine egress. With increased temperature, intact cystine may be transported out of the lysosomal compartment by a transport system whose structural specificity is modified so that cystine is now a substrate. Bashan et al. [14] recently proposed a similar mechanism to account for cystine egress from cystinotic lysosomes in the presence of $\mathrm{K}^{+}$and ionophores.

Since proteolysis increases at elevated temperature [11], we initially reasoned that the cystine content of cystinotic lysosomes should increase under these conditions. However the unexpected observation that cystine is depleted from cystinotic fibroblasts under these conditions adds an unexpected aspect to this facet of the study of cystinotic fibroblasts. It remains possible that a temperature-induced increase in the rate of lysosomal proteolysis initially overwhelms the ability of the presumed newly activated cystine transport system to transport cystine out, and it is only after an initial burst of proteolysis is exhausted that the newly activated cystine transport system can begin to remove detectable amounts of cystine from the lysosomal compartment. This would account both for the lag seen at $40^{\circ} \mathrm{C}$ but not at $43^{\circ} \mathrm{C}$ in intact fibroblasts, and the immediate exodus from isolated granules. Determination of the validity of this hypothesis will require careful measurements of protein turnover at short intervals immediately after exposure to elevated temperatures, as well as careful measurement of the rate of egress of the vacuolar contents during the same interval.

There also may be some clinical applications derived from these observations. Cystinosis is diagnosed in vitro by the measurement of $\left[{ }^{35}\right.$ S $]$ cystine accumulation in cultured amniocytes [4]. A possible failure to diagnose an affected fetus could result if the incubation temperature of the cells was accidentally increased during the labelling period.

Secondly, we have shown improved growth and stabilized renal function in patients who are depleted of their lysosomal cystine content by longterm treatment with cysteamine [15]. It is possible that localized diathermy to the kidneys could also produce significant cystine depletion with beneficial effect.

\section{Acknowledgements}

Supported in part by grants AM 25548 and AM 32281 from the National Institutes of Health. We thank Phyllis Newberry for excellent secretarial assistance. 


\section{References}

1 Gahl, W., Tietze, F., Bashan, N., Steinherz, R. and Schulman, J. (1982) J. Biol. Chem. 257, 9570-9575

2 Gahl, W., Bashan, N., Tietze, F., Bernadini, I. and Schulman. J. (1982) Science 217, 1263-1265

3 Jonas, A., Smith, M. and Schneider, J. (1982) J. Biol. Chem. 257, 13185-13188

4 Schneider, J. and Schulman, J. (1983) in The Metabolic Basis of Goldstein, J. and Brown, M., eds.), 5th Edn., pp. 1844-1866, McGraw-Hill, New York

5 Pisoni, R., Thoene, J. and Christensen, H. (1985) J. Biol. Chem. 260, 4791-4798

6 Pisoni, R., Flickinger, K., Thoene, J. and Christensen, H. (1986) Fed. Proc. 45, 1759

7 Oshima, R., Willis, R., Furlong, C. and Schneider, J. (1974) J. Biol. Chem. 249, 6033-6039
8 Lowry, O.H., Rosebrough, N.I., Farr, A.L. and Randall, R.J. (1951) J. Biol. Chem. 193, 265-275

9 Laemmli, U.K. (1970) Nature (Lond.) 227, 680-685

10 Steinherz, R., Tietze, F., Raiford, D., Gahl, W. and Schulman, J. (1982) J. Biol. Chem. 257. 6041-6049

11 Craig, E. (1985) CRC Crit. Rev. Biochem. 18, 239-280

12 Ciechanover, A., Finley, D. and Varshavsky, A. (1984) Cell, 37, 57-66

13 Thoene, J., Lemons, R., Boskovich, S. and Borysko, K (1985) J. Clin. Invest. 75, 370-376

14 Bashan, N., Gahl, W., Tietze, F., Bernardini, I. and Schulman, J. (1984) Biochim. Biophys. Acta 777, 267-273

15 Thoene, J. (1985) in Cooperative Approaches to Research and Development of Orphan Drugs (VanWoert, M. and Chung, E., eds.), pp. 157-162, Alan R. Liss, New York 